Fragments of the City 



\section{Fragments of the City}

Making and Remaking Urban Worlds

\section{Colin McFarlane}

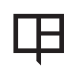


University of California Press

Oakland, California

(C) $202 \mathrm{I}$ by Colin McFarlane

Library of Congress Cataloging-in-Publication Data

Names: McFarlane, Colin, I979- author.

Title: Fragments of the city : making and remaking urban worlds / Colin McFarlane.

Description: Oakland, California : University of California Press, [202I] I Includes bibliographical references and index.

Identifiers: LCCN 2O2IOI2I 2I I ISBN 9780520382237 (hardcover) I ISBN 9780520382244 (paperback) I ISBN 978052038225 I (ebook)

Subjects: LCSH: Cities and towns. I Cities and towns in literature.

Classification: LCC HTI 5 I .M388 202I I

DDC 307.76 - dc23

LC record available at https://lccn.loc.gov/2O2 IOI 2 I 2 I

Manufactured in the United States of America

$\begin{array}{llllllllll}30 & 29 & 28 & 27 & 26 & 25 & 24 & 23 & 22 & 21\end{array}$

$\begin{array}{llllllllll}\text { IO } & 9 & 8 & 7 & 6 & 5 & 4 & 3 & 2 & \text { I }\end{array}$ 